\title{
Isi atau Materi Pendidikan: (Iman, Islam, Ihsan, Din, Amal Saleh)
}

\author{
Siti Halimah \\ Sekolah Tinggi Agama Islam Rokan Bagan Batu Rokan Hilir \\ Email: sitihalimahfaiza@gmail.com
}

\begin{abstract}
Abstrak
Penelitian ini bertujuan untuk mengungkap Isi Atau Materi Pendidikan: (Iman, Islam, Ihsan, Din, Amal Saleh). Metode dalam penelitian ini menggunkan metode kualitatif dengan teknik analisis konten analisis. Jenis data yang digunakan yaitu berupa data sekunder. Penelitian dilakukan dengan mengidentifikasi permasalahan yang terjadi pada pendidikan agma Islam di perguruan tinggi umum. , kemudian data dikumpulkan, dianalisis dan disimpulkan sesuai kebutuhan yang mungkin dapat menjadi penyelesaian masalah tersebut berupa strategi pengembangan kurikulum dalam pembelajaran pendidikan agama Islam di perguruan tinggi umum dengan menggunakan studi kepustakaan Dari pemaparan diatas, maka dapat diambil beberapa kesimpulan sebagai berikut: 1) Islam, Iman, Ihsan, Ad-din, dan Amal saleh adalah satu kesatuan yang tidak bisa dipisahkan satu dengan lainnya. Islam adaalah satu-satunya agama yang diakui Allah di sisi-Nya, sedangkan Iman adalah keyakinan yang menjadi dasar akidah Islam. 2) Subtansi dari materi pendidikan Islam haruslah mencakup konsep iman, Islam dan Ihsan. Agar peserta didik setelah mengalami proses pendidikan membuatnya menjadi insan kamil dengan pola takwa. Insan kamil artinya manusia utuh jasmani dan rohani, dapat berkembang secara wajar dan normal karena takwanya kepada Allah SWT. 3) Materi pembelajaran Pendidikan Islam berbasis Islam, Iman, Ihsan, Ad-din, dan Amal saleh ialah bertujuan mengintregasikan ketiga pilar ini dalam materi ajar yang disampaikan kepada peserta didik. Sehingga peserta didik tidak hanya paham secara teori saja namun dapat merealisasikan teori tersebut dalam kehidupan sehari-hari.
\end{abstract}

Key Words: Iman; Islam; Ihsan; Din; Amal Saleh

\section{PENDAHULUAN}

Dunia pendidikan merupakan wadah interaksi dalam mengembangkan potensi yang dimiliki siswa. Proses interaksi dalam proses belajar-mengajar tersebut erat kaitannya dengan transfer of knowledge (mentransfer pengetahuan dan pengalaman) dan juga transfer of value (mentransfer nilai-nilai moral dan kebaikan) (Sawaluddin, 2017). Dalam konteks ilmu pendidikan, ada dua hal yang tidak boleh diabaikan yaitu materi dan metode pembelajaran (Laila Hamidah, Sawaluddin Siregar, Nuraini Nuraini, 2019). Sedangkan dalam konteks pendidikan Islam, materi dan metode pembelajaran tersebut harus merujuk pada nilai-nilai prophetik Nabi Muhammad Saw.

Perjalanan Rasulullah Saw dalam setiap misi mengajarnya tidak lepas dari apa yang akan diajarkan, dan bagaimana beliau mengajarkannya kepada Sahabat (Abdullah AS, Achyar Zein, Saleh Adri, 2017). Merujuk pada pola pendidikan dan keguruan Rasulullah Saw, dalam perspektif Islam, guru menjadi posisi kunci dalam membentuk kepribadian muslim yang sejati (Sawaluddin, Sainab, 2019). Selanjutnya adalah penguasaan materi dan metode pembelajaran yang sesuai dengan nilai-nilai prophetik Nabi Muhammad Saw (Sawaluddin Sawalud din, et.al, 2018). 
Oleh karena itu, memahami konteks pendidikan Islam dengan pendekatan prophetik saat ini sangat menarik untuk dikaji lebih jauh. Bila dilihat dari sisi kehidupan Rasulullah Saw sebagai murobbi menjadikan beliau harus memiliki seribu satu cara jitu untuk menyampaikan esensi-esensi dari firman Allah Swt dan Sunnahnya, ini merupakan bagian dari ekspansi Islam (Zakiah Darajat, 1995).

Peristiwa dua puluh tiga tahun ini, dimana Islam tersebar secara luas bahkan masih berkembang sampai saat ini. Tentu ada sesuatu dibalik seribu satu cara Rasulullah Saw. Kajian tentang cara-cara ini tidak banyak yang mengkajinya oleh tokoh-tokoh klasik, hadishadis itu lebih banyak masuk kepada sub bab tentang esensi dari matan hadis itu. Namun hadishadis Rasulullah Saw tidak sedikit yang berbicara soal proses pembelajaran bila kita lihat dari sisi pendidikan. Rasul sendiri juga memiliki tempat mengajar, yaitu di timur masjid Nabawi, di Raudhoh, bersandar ke dinding kamar Sayyidah 'Aisyah ra (Naufal bin Muhammad al-'Aidarus, 2015).

Ditempat itulah biasanya Rasulullah Saw diwaktu dhuha setelah sholat mengajarkan ilmu kepada sahabatnya. Salah satu hadis yang dikaji ini juga terjadi disaat Rasulullah Saw sedang berkumpul bersama para sahabatnya dalam majlis ilmu. Hadist yang diriwayatkan oleh Muslim no. 8 kebanyakan ulama memasukannya dalam sub bab yang berkaitan dengan matan hadis ini, yaitu Iman, Islam, Ihsan.

\section{METODE}

Metode dalam penelitian ini menggunkan metode kualitatif dengan teknik analisis konten analisis. Jenis data yang digunakan yaitu berupa data sekunder. Penelitian dilakukan dengan mengidentifikasi permasalahan yang terjadi pada pendidikan agma Islam di perguruan tinggi umum., kemudian data dikumpulkan, dianalisis dan disimpulkan sesuai kebutuhan yang mungkin dapat menjadi penyelesaian masalah tersebut berupa strategi pengembangan kurikulum dalam pembelajaran pendidikan agama Islam di perguruan tinggi umum dengan menggunakan studi kepustakaan.

\section{HASIL DAN PEMBAHASAN}

\section{Isi Atau Materi Pendidikan}

Materi pendidikan berarti mengor ganisir bidang ilmu pengetahuan yang membentuk basis aktivias lembaga pendidikan, bidang-bidang ilmu pengetahuan ini satu dengan lainnya dipisah-pisah namun merupakan satu kesatuan terpadu. Materi pendidikan harus mengacu pada tujuan, bukan sebaliknya tujuan mengarah kepada suatu materi, oleh karenanya materi pendidikan tidak boleh berdiri sendiri sendiri terlepas dari kontrrol tujuannya (Abdullah Abdurrahman Saleh, 2007).

Isi atau materi pelajaran merupakan komponen kedua dalam sistem pembelajaran. Dalam konteks tertentu, materi pelajaran merupakan inti dalam proses pembelajaran (Siti Halimah, 2020). Artinya, sering terjadi dalam proses pembelajaran diartikan sebagai proses penyampaian materi. Hal ini bisa dibenarkan manakala tujuan utama pembelajaran adalah penguasaan materi pembelajaran (subject centered teaching). Dalam kondisi semacam ini, maka penguasaan materi pelajaran oleh guru mutlak diperlukan (Siti Halimah, 2020). Guru perlu memahami secara detail isi materi pelajaran yang harus dikuasai siswa, sebab peran dan tugas guru adalah 
sebagai sumber belajar (Irpan Abd.Gafar, 2006).

Materi pelajaran tersebut biasanya digambarkan dalam buku teks, sehingga sering terjadi proses pembelajaran adalah menyampaikan materi yang ada dalam buku. Namun demikian, dalam setting pembelajaran yang berorientasi pada pencapaian tujuan atau kompetensi, tugas dan tanggung jawab guru bukanlah sebagai sumber belajar. Dengan demikian, materi pelajaran sebenarnya bisa diambil dari berbagai sumber (Wina Sanjaya, 2016). Materi pembelajaran atau materi ajar (instructional materials) adalah pengetahuan, sikap dan keterampilan yang harus dipelajari siswa dalam rangka mencapai standar kompetensi yang telah ditentukan.

Materi pelajaran diartikan pula sebagai bahan pelajaran yang harus dikuasai oleh siswa sesuai dengan tujuan pembelajaran. Peran materi pembelajaran dalam proses pendidikan menempati posisi yang sangat strategis dan turut menentukan tercapainya tujuan pendidikan, karena materi pembelajaran merupakan input instrumental (instrumental input) bersama dengan kurikulum/program pendidikan, guru, media, evaluasi, dan sebagainya. Materi pembelajaran merupakan salah satu aspek yang dapat mempengaruhi output.

Dengan kata lain kualitas proses dan hasil pendidikan, dapat dipengaruhi oleh materi pembelajaran yang digunakan. Atas dasar itulah, dalam sistem pendidikan, materi pembelajaran memegang peran yang cukup penting dan menentukan. Tugas guru disini adalah bagaimana guru dapat menyampaikan atau menyajikan materi pelajaran dengan semenarik mungkin, sehingga siswa termotivasi untuk mengikuti proses belajar mengajar dengan baik dan penuh semangat. Usaha yang dapat dilakukan oleh guru adalah mengkombinasi dan mengkoordinasikan materi pelajaran dengan media dan strategi pembelajaran yang relevan. Hal ini tentu saja harus didukung dengan penguasaan materi atau bahan pelajaran yang ia sajikan dengan penggunaan bahasa yang baik dan benar (Syaiful Sagala, 2010).

Diantara materi yang bersumber dari agama antara lain seperti: 1) Islam, 2) Iman, 3) Ihsan, 4) Ad-din ,dan 5) Amal saleh. Berikut penjelasan dari lima aspek isi atau materi pendidikan tersebut.

\section{Iman}

Iman berasal dari Bahasa Arab dari kata dasar amana yu'minuimanan. Artinya beriman atau percaya. Percaya dalam Bahasa Indonesia artinya meyakini atau yakin bahwa sesuatu (yang dipercaya) itu memang benar atau nyata adanya (Kaelany HD, 2000). Iman dapat dimaknai iktiraf, membenarkan, mengakui, pembenaran yang bersifat khusus (Abdul Rahman Abdul Khalid, 1996). Menurut WJS. Poerwadarminta iman adalah kepercayaan, keyakinan, ketetapan hati atau keteguhan hati (WJS. Poerwadarminta, 2000).

Abul 'Ala al-Mahmudi menterje mahkan iman dalam Bahasa inggris Faith, yaitu to know, to believe, to be convinced beyond the last shadow of doubt yang artinya, mengetahui, mempercayai, meyakini yang didalamnya tidak terdapat keraguan apapun (Abu A'la Al-Maududi, 1985). HAR Gibb dan JH Krammers memberikan pengertian iman ialah percaya kepada Allah, percaa kepada utusan-Nya, dan percaya kepada amanat atau apa yang dibawa/berita yang dibawa oleh utusannya (HAR. Gibb and JH Krammers, 1974). Bila kita perhatikan 
penggunaan kata Iman dalam Al- Qur'an, akan mendapatinya dalam dua pengertian dasar,11 yaitu: 1) Iman dengan pengertian membenarkan adalah membenarkan berita yang datangnya dari Allah dan Rasul-Nya.

Dalam salah satu hadist shahih diceritakan bahwa Rasulullah ketika menjawab pertanyaan Jibril tentang Iman yang artinya bahwa yang dikatakan Iman itu adalah engkau beriman kepada Allah, malaikat-Nya, kitab-kitab-Nya, Rasulrasul-Nya, hari kiamat dan engkau beriman bahwa Qadar baik dan buruk adalah dari Allah SWT. 2) Iman dengan pengertian amal atau ber-iltizam dengan amal : segala perbuatan kebajikan yang tidak bertentangan dengan hukum yang telah digariskan oleh syara'. Dalam sebuah ayat dalam al-quran surat alhujarot: ayat 15 :

Dari ayat tersebut, dapat dikatakan bahwa Iman adalah membenarkan Allah dan RasulNya tanpa keraguan, berjihad di jalan Allah dengan harta dan jiwa. Pada akhir ayat tersebut "mereka Itulah orangorang yang benar" merupakan indikasi bahwa pada waktu itu ada golongan yang mengaku beriman tanpa bukti, golongan ini sungguh telah berdusta danmereka tidak dapat memahami hakikat iman dengan sebenarnya. Mereka menganggap bahwa iman itu hanya pengucapan yang dilakukan oleh bibir, tanpa pembuktian apapun. Inti pendidikan agama terletak pada pendidikan keimanan (Nur Hadi, 2019).

Para psikolog berpendapat bahwa dalam keimanan kepada allah Swt. Terdapat kekuatan spiritual luar biasa yang dapat membantu orang beriman mengatasi kegelisahan, ketegangan, dan kesulitan hidup di zaman modern ini (Muhammad Usman Najati, tt). Dunia modern yang telah dikuasai oleh kehidupan material dan di dominasi oleh persaingan keras untuk mendapatkan materi, telah menimbulkan ketegangan, stress, dan kegelisahan, atau bahkan penyakit kejiwaan lainnya dalam diri manusian yang miskin akan nilai spiritual.

Seorang psikoanalisis, A.A. Brill berkata bahwa "orang yang beragama secara benar sama sekali tidak akan menderita penyakit kejiwaan". Berdasarkan eksperimennya, orang beragama yang terbiasa mendatangi tempat-tempat ibadah mempunyai kepribadian yang lebih baik daripada mereka yang tidak beragama atau yang tidak menjalankan ibadah apapun (Muhammad Usman Najati, tt).

AlQur'an menjelaskan perasaan aman dan tentram karena adanya iman di hati dalam surat Ar Ra'd ayat 28. Dari ayat tersebut jelas bahwa ingat kepada Allah merupakan salah satu Nya. Iman kepada Allah juga dapat diwujudkan dengan jalan mengikuti semua tuntunan yang telah digariskanNya. Hal itulah satu-satu nya cara untuk mewujudkan rasa aman bagi manusia dan membebaskannya dari kegelisahan hidup (Sawaluddin Siregar, 2020). Pendidikan iman yang dilakukan hendaknya didasarkan kepada wasiat dan petunjuk Rasulullah dalam menyampaikan dasardasar keimanan kepada anak. Sebab dalam diri Rasulullah terdapat teladan yang baik bagi setiap orang sebagaimana disebutkan dalam surat Al Ahzab ayat 21.

Untuk mencapai hasil pendidikan keimanan yang diharapkan, sudah pasti tak dapat dilakukan tanpa mengikuti jejak dan teladan Rasulukllah saw. secara tepat dan benar Salah satunya adalah dengan merujuk kepada contoh dan teladan 
beliau yang dipaparkan dalam hadisthadist yang shahih. Dalam salah satu hadist, beliau memaparkan bahwa akidah Islam itu mempunyai enam aspek (unsure, rukun), yakni iman kepada Allah, para malaikat-Nya, kitabkitabNya, para Rasul-Nya, iman kepada hari akhir dan juga kepada segala ketentuan yang digariskan-Nya.

Sejarah telah membuktikan bahwa pendidikan keimanan kepada anak yang benar-benar berhasil mewarnai tata kehidupan masyarakat muslim hayalah yang ditunjukkan para sahabat Rasulullah saw. sebagai hasil perjuangan beliau. Rasulullah tidak hanya memberikan teori yang tidak dibuktikan dalam kehidupan konkritnya, tetapi justru memberikan contoh da tuntunan praktis yang diperlukan dalam mendidik anak berdasarkan tauhid. Para sahabat meriwayatkan hadist tentang praktek beliau tersebut, banyak diantaranya yang masih berusia anak-anak. Mereka inilah yang mengalami secara langsung didikan Rasulullah dalam bidang keimanan (Muhammad Thalib, 2000).

Menurut Muhammad Nur Abdul Hafizh, setidaknya terdapat lima pola dasar pembinaan akidah atau keimanan yang sesuai dengan petunjuk Rasulullah, yakni : a) Membacakan kalimat tauhid kepada anak b) Menanamkan kecintaan anak kepada Allah Swt. c) Menanamkan kecintaan anak kepada Rasulullah d) Mengajarkan Al-Qur'an kepada anak e) Menanamkan nilai perjuangan dan pengorbanan dalam diri anak (Muhammad Nur Abdul Hafizh Suwaid, 2000).

\section{Islam}

Kata Islam berasal dari bahasa Arab "S-L-M" ( Sin, Lam, Mim). Artinya antara lain: Damai, Suci, Patuh dan Taat (tidak pernah membantah) (Muhammad Abduh, 1992). Dalam pengertian agama, kata Islam berarti kepatuhan kepada kehendak dan kemauan Allah, serta taat kepada hukum-Nya (Muhammad AtTamimiy, 2017). Hubungan antara pengertian menurut kata dasar dan pengertian menurut agama erat dan nyata sekali, yaitu: "Hanya dengan k epatuhan kepada kehendak Allah dan tunduk kepada hukum-hukum-Nya seorang dapat mencapai kedamaian yang sesungguhnya dan memperoleh kesucian ang abadi" (Hammudah Abdalati, 1983).

Islam, menurut Zuhairini, adalah menempuh jalan keselamatan dengan yakin menyerahkan diri sepenuhnya kepada Tuhan dan melaksanakan dengan penuh kepatuhan dan ketaatan akan segala ketentuanketentuan dan aturanaturan oleh-Nya untuk mencapai kesejahteraan dan kesentosaan hidup dengan penuh keimanan dan kedamaian (Zuhairini, 1995). Agama Islam mempunyai pengertian yang lebih luas dari pengertian agama pada umumnya.

Di sini, kata Islam berasal dari Bahasa Arab yang mempunyai bermacam-macam arti, diantaranya sebagai berikut:

a. Salam yang artinya selamat, aman sentosa dan sejahtera, yaitu aturan hidup yang dapat menyelamatkan manusia di dunia dan akhirat. Kata salam terdapat dalam alQur'an Surah al-An'am ayat 54; Surah al-A'raf ayat 46; dan surah an-Nahl ayat 32 .

b. Aslama yang artinya menyerah atau masuk Islam, yaitu agama yang mengajarkan penyerahan diri kepada Allah, tunduk dan taat kepada hukum Allah tanpa tawar- menawar. Kata aslama terdapat dalam al-Qur'an surah al-Baqarah ayat 112; surah al-Imran 
ayat 20 dan 83; surah an-Nisa ayat125; dan surah al-An'am ayat 14 .

c. Silmun yang artinya keselamatan atau perdamaian, yakni agama yang mengajarkan hidup yang damai dan selamat.

d. Sulamun yang artinya tangga, kendaraan, yakni peraturan yang dapat mengangkat derajat kemanusiaan yang dapat mengantarkan orang kepada kehidupan yang bahagia (M. Yatimin Abdullah, 2006).

Adapun kata Islam menurut istilah (terminologi) adalah mengacu kepada agama yang bersumber pada wahyu yang datang dari Allah SWT, bukan berasal dari manusia. Sebagai agama sempurna, Islam datang untuk menyempurnakan ajaran yang dibawa oleh Nabi-nabi Allah sebelum Nabi Muhammad. Kesempur naan ajaran ini menjadi misi profetik (nubuwwah) kehadiran Nabi Muhammad SAW. Dalam al-Qur'an (Surah alMa'idah [5]: 3) ditemukan penegasan tentang kesempurnaan ajaran Islam.

Term ihsan berasal dari huruf alif, ha, sin dan nun . Di dalam alQur'an, kata ihsan bersama dengan berbagai derivasi dan kata jadiannya disebutkan secara berulang -ulang. Penyebutan tersebut terdapat sebanyak 108 kali yang disebut tersebar dalam 101 ayat dan pada 36 surat.19 Derivasi ihsan berupa fi'il mâdhi, ahsana disebut dalam al-Qur'an sebanyak 9 (sembilan) kali pada 9 (sembilan) ayat dan 8 (delapan) surat. Sedangkan kata ahsantum diulang sebanyak 2 (dua) kali pada 1 (satu) ayat dan 1 (satu) surat. Sementara ahsanû tercantum 6 (enam) kali pada 6 (enam) ayat dan 6 (enam) surat. Perbedaan ungkapan tersebut terletak pada fâ'il-nya (subjek) yang secara umum terdiri dari
Allah dan manusia, baik berupa isim zhâhir maupun isim dhamîr.

Lebih lengkapnya, berikut ini adalah daftar jumlah kata ihsan dengan berbagai derivasinya dalam al-Qur'an Lafadz dari huruf alif, ha, sin dan nun ini, selain menghasilkan term ihsan beserta derivasinya, juga dihasilkan pula term hasuna beserta derivasinya. Meski memiliki makna umum yang serupa, tapi kedua makna ini tidak berkonotasi ihsan. Ayat ihsan yang bersinggungan dengan bakti terhadap orangtua memang mendominasi. Berdasarkan maknanya, kelima ayat tersebut dapat dikelompokkan dalam dua kelompok.

Kelompok pertama adalah ayat -ayat yang mengandung perintah untuk berbuat baik kepada kedua orangtua (ibu-bapak) dan juga kepada orang lain, seperti kerabat, anak yatim, orang-orang miskin, tetangga dekat, tetangga jauh, teman sejawat, ibn sabil dan hamba sahaya, dan disertai pula dengan perintah beribadah semata-mata hanya kepada Allah dan tidak menyekutukan-Nya dengan sesuatu apa pun. Perintah ini secara eksplisit tertuang dalam surat al-Baqarah [2] : 83.

Ayat yang disebutkan di atas menunjukkan perbuatan ihsan yang mengarah pada bentuk perbuatan baik yang dilakukan oleh manusia. Perbuatan baik ini secara terkhusus dilakukan sebagai bentuk ibadah menyembah Allah ekaligus dengan diiringi bentuk perbuatan baik yang dilakukan manusia kepada sesamanya. Bila dimaknai lebih lanjut, ibadah manusia yang dilakukan dengan menyembah Allah dan tidak mempersekutukan Allah ini disertai dengan kewajiban -kewajiban lain yang berhubungan dengan perbuatan baik kepada sesama manusia. Di mana keutamaan perbuatan baik ini dilakukan terhadap kedua orangtua. 


\section{Din}

Dalam Istilah Syar'i, kata Din dan Millah berarti: Makna kata Ad-Din (Jubran Mas'ud, 1992) dalam al-Qur`an yaitu agak (al-hisab), pembangkitan (alba`ts), pembalasan (al-jaza), ketetapan (al-qodho), ganjaran (ats-tsawab), siksaan (al-iqob), ibadah, doa, tauhid, ketaatan, agama, dan hukum (Ahmad Warson Munawwir, 1997).

Banyak kata Ad-Din dipercakapkan sebanyak 92 kali dalam Al-Qur`an yang terdapat dalam 82 ayat. Kata Al-Millah dikata dalam Al-Qur'an sebanyak 10 kali. Sedangkan penggunaan kedua kata tersebut dalam al-Qur'an yaitu:

a. Kata Ad-Din mempunyai faedah agak (al-hisab), pembangkitan (al-ba`ts), pembalasan (al-jaza), ketetapan (alqodho), ganjaran (ats-tsawab), siksaan (al-iqob), ketika al-Quran membicarakan tentang hari qiyamat . sebagaimana terdapat dalam surat alfatihah : 4, al-hijr : 35, an-nur : 25, asy-syuara : 82 , as-shofat : 20 , shod : 78, adz-dzariyat: 6, 12, al-waqiah : 56 , al-maarij : 26 , al-mudatsir : 46 , alinfithor : 9, 15, 17, 18, al-muthofifin : 11, at-tin : 7 al-maun : 1 .

b. Kata Ad-Din mempunyai makna ibadah, doa, tauhid, ketaatan ketika alQuran membahas tentang pemurnian terhadap Allah. Seperti yang terdapat pada surat al-baqoroh : 193, an-nisa : 146, al-a raf : 29, al-anfal : 39 , yunus : 22, yusuf : 40, an-nahl : 52, alankabut : 65, ar-ruum : 30, luqman : 32, az-zumar : 2, 3, 11, 14, ghofir : 14 , 65, al-bayyinah : 5 .

c. Kata Ad-Din mempunyai faedah hukum dan ketetapan ketika al-Quran membahas mengenai pengambilan hukum yang dimainkan olehNya maupun yang dimainkan oleh
hambaNya seperti dalam surat yusuf : 76, an-nur : 2.

d. Kata Ad-Din bermakna Al-Millah dan syariat ketika beliau tidak kekurangan dalam kontek pembahasan penetapan syariat tuhan terhadap hambaNya. Sebagaimana dalam surat al syura: 13, ar-ruum : 3

e. Kata Ad-Din berfaedah sesuatu yang dianut oleh manusia ketika tidak kekurangan dalam konteks pembahasan mengenai keyakinan seperti dalam surat al mumtahanah : 8 , 9, al-fath : 28, al-ahzab : 5, ali-imran : 24, an-nisa : 60 al-kafirun : 6 .

f. Kata Al-Millah mempunyai faedah sesuatu yang dianut oleh seseorang (Ad-Din) ketika beliau tidak kekurangan dalam konteks pembahasan mengenai keyakinan yang dianut oleh seseorang. Seperti dalam surat al baqarah: 135, alan`am : 161, shod : 7 .

g. Kata Al-Millah mempunyai faedah syariat ketika beliau tidak kekurangan dalam kenteks pembahasan mengenai penetapan syariat tuhan terhadap hambaNya. Seperti dalam surat aliimran : 95, al-haj : 78

\section{Amal Saleh}

Amal saleh terdiri dari dua kata yang masing-masing memiliki pengertian sendiri. Amal adalah semua perbuatan yang dikerjakan dan dengan niat tertentu. Dalam al-Quran kata amal jika dilihat dari maknanya sebagai perbuatan, maka berdekatan dengan beberapa kata atau ungkapan lain. Seperti fi'il, sa'yu, shan'u, kasab, dan jarah. Letak persamaan antara semua ungkapan tersebut adalah kesemuanya meliputi perbuatan manusia.

Namun walaupun secara makna mereka berdekatan tetapi masing-masing memiliki fokus makna yang berbeda. 
Semisal antara kata amal dan . Amal memiliki makna yang lebih khusus dari kata fi'il. Term amal hanya khusus merujuk pada perbuatan-perbuatan yang dilakukan manusia dan hewan, sedangkan term fi'il juga digunakan untuk menunjuk perbuatan benda-benda mati (Al-Raghib al-Asfahani, 2004).

Begitupun dengan ungkapanungkapan lainnya, memiliki perbedaan makna dengan term amal. Term amal kemudian berderivasi menjadi kata mu'amalah. Sebuah term dengan wazan yang menunjukan makna hubungan/ aturan tingkah laku antara satu manusia dengan manusia lainnya (Jamal, K. and Sawaluddin, 2020). Istilah mu'amalah ini sangat popular dalam kajian hukum islam, saat membedakan antara prilaku manusia yang hubungan nya dengan Tuhan dan yang hubungan nya dengan sesama manusia (Hubungan dengan Allah disebut dengan ibadah dan hubungan dengan manusia disebut dengan (Mahsun Fuad, 2005).

Derivasi dari kata amal kepada term mu'amalah ini yang memberikan pengertian tambahan kepada term amal bahwa di dalamnya terdapat keniscayaan perbuatan yang mempertemukan manusia dengan manusia yang lain. Dari sini maka amal-muamalah akhirnya terkadang disejajarkan pula dengan istilah akhlaq dan etika (Qurais Syihab, 1988).

Sebab semuanya dianggap berkaitan dengan pembicaraan tentang aturan laku yang terdapat dalam hubungan antara sesama manusia. Adapun Metode pelaksanaan amal shaleh yang bisa diterapkan dilembaga pendidikan islam adalah dengan metode berikut; 1) Ceramah dan Tanya Jawab 2) Demonstras 3) Pemberian tugas. 4)
Muhasabah 5) Eksperimen 6) Talqin 7) Musyawaroh. 8) Mujahadah

\section{Korelasi Islam, Iman, Ihsan, Ad-din , dan Amal saleh}

Secara teori Islam, Iman, Ihsan, Ad-din, dan Amal saleh dapat dibedakan namun dari segi prakteknya tidak dapat dipisahkan. Satu dan lainnya saling mengisi, iman menyangkut aspek keyakinan dalam hati yaitu kepercayaan atau keyakinan, sedangkan Islam artinya keselamatan, kesentosaan, patuh, dan tunduk dan ihsan artinya selalu berbuat baik karena merasa diperhatikan oleh Allah (Alfiah dan Zalyana, 2011). Beribadah agar mendapatkan perhatian dari sang Khaliq, sehingga dapat diterima olehnya. Tidak hanya asal menjalankan perintah dan menjauhi laranganNya saja, melainkan berusaha bagaimana amal perbuatan itu bisa bernilai plus dihadapan-Nya. Sebagaimana yang telah disebutkan diatas kedudukan kita hanyalah sebagai hamba, budak dari Tuhan, sebisa mungkin kita bekerja, menjalankan perintah-Nya untuk mendapatkan perhatian dan ridhoNya (Abdullah Abdurrahman Saleh, 2007).

\section{KESIMPULAN}

Dari pemaparan diatas, maka dapat diambil beberapa kesimpulan sebagai berikut:

1. Islam, Iman, Ihsan, Ad-din, dan Amal saleh adalah satu kesatuan yang tidak bisa dipisahkan satu dengan lainnya. Islam adaalah satusatunya agama yang diakui Allah di sisi-Nya, sedangkan Iman adalah keyakinan yang menjadi dasar akidah Islam. Keyakinan tersebut kemudian diwujudkan melalui pelaksanaan kelima rukun Islam. Sedangkan pelaksanaan rukun Islam 
dilakukan dengan cara Ihsan, sebagai upaya pendekatan diri kepada Allah dan barometer tingkat keimanan dan ketaqwaan seorang hamba. Maka Islam tidak sah tanpa Iman, dan iman pun tidak sempurna tanpa ihsan. Sebaliknya, ihsan adalah mustahil tanpa iman, dan iman pun tidak akan terwujud tanpa adanya Islam.

2. Subtansi dari materi pendidikan Islam haruslah mencakup konsep iman, Islam dan Ihsan. Agar peserta didik setelah mengalami proses pendidikan membuatnya menjadi insan kamil dengan pola takwa. Insan kamil artinya manusia utuh jasmani dan rohani, dapat berkembang secara wajar dan normal karena takwanya kepada Allah SWT.

3. Materi pembelajaran Pendidikan Islam berbasis Islam, Iman, Ihsan, Ad-din, dan Amal saleh ialah bertujuan mengintregasikan ketiga pilar ini dalam materi ajar yang disampaikan kepada peserta didik. Sehingga peserta didik tidak hanya paham secara teori saja namun dapat merealisasikan teori tersebut dalam kehidupan sehari-hari

\section{REFERENSI}

Abdul Rahman Abdul Khalid, Garis Pemisah antara Kufur dan Iman, Jakarta, Bumi Aksara,1996

Abdullah Abdurrahman Saleh, TeoriTeori Pendidikan Berdasarkan AlQur'an. Jakarta; Rineka Cipta. 2007

Abdullah Abdurrahman Saleh, TeoriTeori Pendidikan Berdasarkan AlQur'an. Jakarta; Rineka Cipta. 2007

Abdullah AS, AchyarZein, SalehAdri, AtTahdis, Journal of Hadist Studies, Vol. 1 No. 2 Juli-Desember, 2017
Abu A'la Al-Maududi,

Toward Understanding, Comiti Riyadh: Islamic Dakwah, 1985

Ahmad Warson Munawwir, Kamus Arab - Indonesia Surabaya: Pustaka Progresif, 1997

Alfiah dan Zalyana, Hadis Tarbawi, Yogyakarta: Nusa Media Yogyakarta, 2011

Al-Raghib al-Asfahani, Mu'jam Mufradat alfaz al-Quran Beirut: Dar al-Kutub al-Ilmiyah, 2004

Hammudah Abdalati, Islam Suatu Kepastian, Media Daeewah, 1983

HAR. Gibb and JH Krammers, Shorter Encyclopaedia of islam, E.J. Brill: Leiden, 1974

Irpan Abd.Gafar, Kurikulum dan Materi Pendidikan Islam, Jurnal Hunafa,Vol. 3 No. 1 Maret 2006

Jubran Mas'ud, Al-Ra'id Beirut:DaralIlmi li al-Malayin, 1992.

Jamal, K. and Sawaluddin, Qur'an and Hadiths in Social Media: Messages of the Qur'an and Hadith in using Social Media, In Proceedings of the 1st International Conference on Recent Innovations (ICRI 2018), SCITEPRESS - Science and Technology, 2020

Kaelany HD, Iman, Ilmu dan Amal Saleh, Jakarta: Rineka Cipta, 2000

Laila Hamidah, Sawaluddin Siregar, Nuraini Nuraini, Kepribadian Guru Pendidikan Agama Islam Menurut Buya Hamka, Tarbiyah: Jurnal Ilmiah Kependidikan e-ISSN: 2548- 8376 Vol. 8 No. 2 Juli Desember 2019

M. Yatimin Abdullah, Studi Islam Kontemporer, Jakarta: Amza, 2006

Mahsun Fuad, Hukum Islam Indonesia; Dari Nalar Partisipatoris Hingga 
Emansipatoris Yogyakarta: LKis, 2005

Muhammad Abduh, Risalah Tauhid (Terjemahan : H. Firdaus), Jakarta: Rajawali Pers, 1992

Muhammad At-Tamimiy, Kitab Tauhid (Jiilid 2), Jakarta: Darul Haq, 2017

Muhammad Nur Abdul Hafizh Suwaid, Mendidik Anak Bersama Rasulullah (terj. Kuswandani dari Manhaj al Tarbiyah al Nabawiyah li al Thifl), Bandung: Al Bayan, 2000.

Muhammad Thalib, Praktek Rasulullah saw. Mendidik Anak (bidang aqidah dan Ibadah) Bandung: Irsyad Baitus Salam, 2000

Muhammad Usman Najati, AlQur'an dan Psikologi, (terj. Ade Asnawi dari Al Qurean wa ilm 1 Nafs, Jakarta: Aras Pustaka, tt

Naufal bin Muhammad al-'Aidarus, Sehari Bersama Rasul: 24 Jam Aktivitas Baginda Muhammad, Surakarta: Taman Ilmu, 2015

Nur Hadi, Islam, Iman Dan Ihsan Dalam Kitab Matan Arba'In An-Nawawi: Studi Materi Pembelajaran Pendidikan Islam dalam Perspektif Hadis Nabi SAW, Jurnal Intelektual: Jurnal Pendidikan dan Studi KeislamanVolume 9, Nomor 1, April 2019

Qurais Syihab, "Iman dan Amal Saleh", Amanah, no 87, November 1988, hlm 177

Sawaluddin Sawaluddin, Koy Sahbuddin Harahap, Muhammad Syaifuddin, Sainab Sainab, Syahrul Akmal Latif, Development of the Potential Senses, Reason, and Heart According to the Qur'an and its Application in Learning, Advances in Social Science, Education and
Humanities Research, volume 253, 3rd Asian Education Symposium (AES 2018), pp.508-511 Sawaluddin Sawaluddin, Munzir Hitami, Zikri Darussamin, Sainab Sainab, The Potential of the Senses in AlQuran as the Basic Elements of the Human Physic and Its Application in Learning, Advances in Social Science, Education and Humanities Research, volume 261, International Conference on Islamic Education (ICIE 2018), pp. 158162.

Sawaluddin Siregar, Hubungan Potensi Indra, Akal, Dan Kalbu Dalam AlQur'an Menurut Para Mufassir AlBanjari: Jurnal Ilmiah Ilmu-Ilmu Keislaman, Vol. 19, No.1, JanuariJuni 2020

Sawaluddin, Potensi Indra, Akal, dan Kalbu Menurut Al-Qur'an dan Aplikasinya Dalam Pengembangan Pendidikan Dasar, Pekanbaru: UIN Suska Riau, Disertasi, 2017, pp. 402-404 Sawaluddin, Sainab, The Intelligent Meaning In The Qur'an: Nalysis Of The Sure Potential In The Al-Qur'an As A Dimension Of Human Psychic Insaniah, Jurnal Madania: Volume 9 2, 2019 (eISSN 2620-8210 | pISSN pp. 373395

Syaiful Sagala, Konsep dan Makna Pembelajaran, Bandung: Alfabeta, 2010

Siti Halimah, Manajemen Pengembangan

Kurikulum Pendidikan Agama Islam Di Mts Irsyadul Islamiyah Rokan Hilir Tarbiyah Islamiyah: Jurnal Ilmiah Pendidikan Agama Islam Volume 10. No 1. Januari Juni 2020 
Siti Halimah, Pengaruh Manajerial

Kepala Madrasah Terhadap

Kinerja Guru Di Ma Irsyadul Islamiyah Rokan Hilir Jurnal PTK \& Pendidikan e-ISSN: 2460-1780 Vol. 6, No. 1, Januari - Juni 2020 (8-12)

Wina, Strategi Pembelajaran Berorientasi Standar Proses Pendidikan Jakarta: Prenadamedia Group, 2016.

WJS. Poerwadarminta, Kamus Umum Bahasa Indonesia, Jakarta: Balai Pustaka, 2000

Zakiah Darajat, Metode Khusus Pengajara nAgama Islam Cet. II, Jakarta: SinarGrafika Offset, 1995

Zuhairini, Filsafat Pendidikan Islam, Jakarta: Rajawali Press, 1995 